Dicle Üniversitesi Veteriner Fakültesi Dergisi
https://dergipark.org.tr/tr/pub/duvetf
Vaka/Case Report
$\begin{gathered}\text { Dicle Üniv Vet Fak Derg 2021;14(1):73-76 } \\ \text { DOI: 10.47027/duvetfd.834158 }\end{gathered}$

\title{
Congenital Pathological Formation of Maxillary Incisive Tooth in The Crossbreed Calf: A Case Report
}

\author{
Servet BADEMKIRAN ${ }^{1, a}$, Simten YEŞiLMEN ALP ${ }^{2, b}$, Elif EKINCi ${ }^{3, c,, 凶}$
}

${ }^{1}$ Department of Obstetrics and Gynaecology, Faculty of Veterinary Medicine, Dicle University, Diyarbakir, TURKEY

${ }^{2}$ Department of Microbiology, Faculty of Veterinary Medicine, Dicle University, Diyarbakir, TURKEY

${ }^{3}$ Department of Wild Animals and Ecology, Faculty of Veterinary Medicine, Dicle University, Diyarbakir, TURKEY

aORCID: 0000-0002-0466-8716; ' ORCID: 0000-0002-2952-5180; 'ORCID: 0000-0002-5067-5685

\begin{tabular}{ccc}
\hline Geliş Tarihi/Received & Kabul Tarihi/Accepted & Yayın Tarihi/Published \\
01.12 .2020 & 09.04 .2021 & 30.06 .2021 \\
\hline
\end{tabular}

\begin{abstract}
In the examination of a five-year-old South Anatolian Red and a Simental cross-breed, dystocia was found to be related to the presentation disorder of the calf. In the clinical examination of the $24-\mathrm{kg}$ male calf delivered by the extraction force, were found to have 7 incisive teeth pathologically in maxilla of the calf. In the following days, in the examinations of the cow, wounds on her mother's udder have appeared depending on the sucking of the calf and consequently mastitis detected. X-rays were taken from various angles to determine the root depth of the roots of the incisive teeth in the maxilla before the operation. Then, incisive teeth were removed with operation from the maxilla accompanied by mild sedation and local anesthesia. It was seen that the calf's non closing mouth due to incisive teeth in maxilla before the operation, return to normal and there was no function problem.
\end{abstract}

Key Words: Anomaly, calf, maxillary incisive tooth

\section{Melez Bir Buzağıda Maxillar İncisive Dişin Doğmasal Patolojik Gelişimi: Vaka Raporu}

Öz

Güç doğum şikâyeti bulunan 5 yaşında Güney Anadolu Kırmızısı (GAK) ve Simental melezi bir ineğin yapılan muayenesinde, güç doğumun buzağının duruş bozukluğuna bağıı olduğu tespit edildi. Doğum krikosu ile doğumu gerçekleştirilen 24 kg'lık erkek buzağının yapılan klinik muayenesinde buzağının üst çene kemiğinde patolojik olarak 7 adet incisive dişe sahip olduğu görüldü. Sonraki günlerde ineğin yapılan muayenelerinde buzağının emmesine bağlı olarak annesinin meme başlarında yaralar ve buna bağlı olarak mastitis şekillendiği tespit edildi. Operasyondan önce üst çene kemiğinde incisive dişlerin köklerinin kök derinliğini belirlemek amacıyla değişik açılardan röntgen çekildi. Daha sonra hafif sedasyon ve lokal anestezi eşliğinde üst çene kemiğindeki incisive dişler operasyonla uzaklaştırıldı. Operasyondan önce üst çene kemiğindeki incisive dişlerden dolayı buzağının kapanmayan ağzı normale döndüğü ve herhangi bir işlev problemi olmadığı görüldü.

Anahtar Kelimeler: Anomali, buzağı, üst çenede incisive diş

\section{INTRODUCTION}

Congenital defects are structural or functional abnormalities present at birth and may affect the single organ of various systems or the functions of the whole system $(1,2)$. It has been reported that anomalies are seen in domestic animals and they can be congenital. Although the cause of some congenital anomalies cannot be fully explained, it has been reported that the majority are related to genetic factors, mutations or chromosomal anomalies, infection agents, environmental factors or combination of these factors $(3,4,5)$.

Genetic defects in cattle can be detected in increasing rates. Genetic selection seems to focus on individual choices. The potential for emergence or recognition of hereditary disorders or anomalies may increase. In addition, inaccurate propagation of genetic defects in animals in this process will reduce genetic development and may also undermine targeted economic impacts (1).

An anomaly can develop in various stages of embryogenesis or fetal development depending on the effects of genetic, environmental or both factors. Mutant genes or chromosomal defects are effective in the formation of hereditary anomalies; It is stated that anomalies due to environmental factors are closely related to stress factors affecting the formation of seasonal or maternal diseases (6). Teeth are an essential organ necessary for speech production as well as taking part in breaking down and crushing food. During tooth development, the dental epithelium and the underlying neural crest-derived ectomesenchyme interact mutually and sequentially for tooth initiation, morphogenesis, and cell differentiation (7). The teeth are an organ used especially food, defense in vertebrates, and speech purposes in humans. Initially, the teeth emerge with the interaction of the tooth epithelium and the neural nerve under the ectomesenchyme while there are no incisors in the upper jaw of ruminants, there are eight incisors in the lower jaw and the upper and lower teeth meet the tooth area called the tooth pad. Milk teeth of calves born toothless or toothless begin to come out in the first months of the postpartum 
period. Temporary incisors are smaller than permanent incisors $(8,9)$. It is known that there are many dental abnormalities in the animal kingdom and are documented by researchers. These abnormalities can affect the structure and number of teeth, shape of teeth, and exfoliation. Occlusal and maxillofacial defects can also occur as a result of dental abnormalities. Such abnormalities may also occur depending on environmental factors that prevent hereditary, fetal or neonatal development $(10,11)$.

It refers to teeth that are formed in addition to hyperdontia or the formation of more than normal teeth. It may occur in any part of the dental arch such as maxilla and mandible, unilateral or bilateral, single or multiple, eruption or discontinuous (7). Hyperdontia, also called polyodontia or supernumerary teeth, is seen most often in the permanent teeth and can affect the incisors, premolars, or molars. Presumably, these teeth arise from overproliferation of the dental lamina during development. Supernumerary teeth tend to cause crowding and malocclusions, which can cause dysphagia, dental disease, and discomfort (12).

\section{CASE DESCRIPTION}

In the examination of a five-year-old South Anatolian Red and a Simental cross-breed, force birth was found to be related to the presentation disorder of the calf. In the clinical examination of the $24-\mathrm{kg}$ male calf delivered by the extraction force, were found to have 7 incisive teeth pathologically in maxilla of the calf (figure 1A). Two of these teeth were dislodged because they were shaken during the examination. In addition, in the clinical examination, it was identified that a portion of the merme of the upper jaw was covered with hair in a pathological manner (figure 1B). In the physical examination, other organs were revealed to be normal. According to the anamnesis findings, it was found that the first two pregnancies were formed by natural insemination_and the calves in other births were not any anomalies. It is reported that in the pregnancy in which the case was formed, natural insemination was performed and an albendazole-derived drug was used only one time for antiparasitic control in a period of 1-2 months of pregnancy.

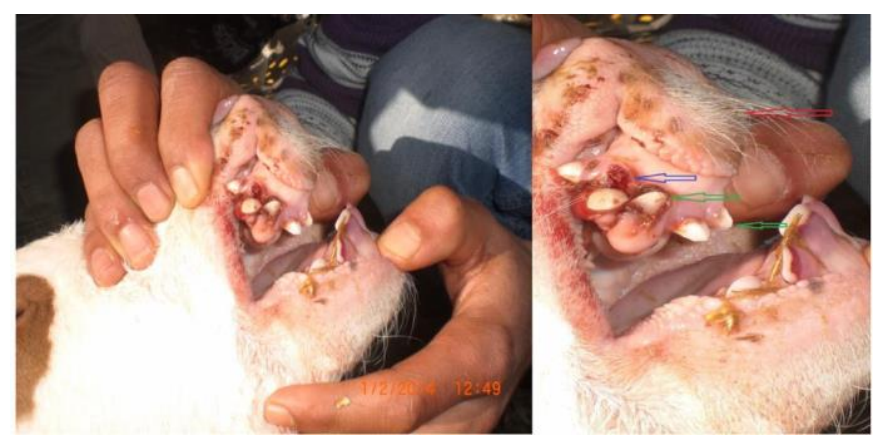

Figure 1. A) Incisive Teeth in Maxilla (green arrows), B) drawn teeth (blue arrows) and the hair on Merme (red arrows)

In the following days, in the examinations of the cow, wounds on her mother's udder have appeared depending on the sucking of the calf (figure 2 ) and consequently mastitis detected.

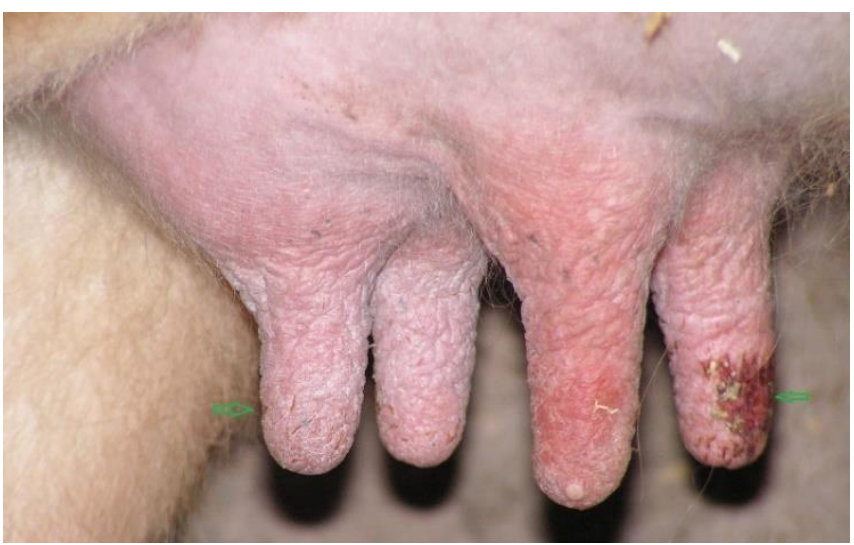

Figure 2. Traumatic wounds of mother's udder due to sucking of calf (Green arrows)

The milk and oral swab samples were taken in sterile tubes and transported to the Laboratory of Microbiology Department in boxes containing ice. Milk sample was centrifuged at $3000 \mathrm{rpm}$ for $15 \mathrm{~min}$, and the precipitate was cultured but swab was used to take direct inoculum on Nutrient agar, Blood agar, Mac Conkey agar and then incubated at $37^{\circ} \mathrm{C}$ for $24 \mathrm{~h}$. The bacterial strains were identified as $\mathrm{S}$. $a u-$ reus by conventional methods, including the morphological character (shape, color and size of colony) catalase activity tests, a tube coagulase tests with rabbit plasma and the mannitol-fermenting tests. The aim of the microbiological study is to reveal the etiological diagnosis of mastitis observed in the mother.

After taking colostrum, bottle feeding of the calf was started to prevent further trauma in the mammary gland. $X$ rays were taken from various angles to determine the root depth of the roots of the incisive teeth in the maxilla before the operation (figure 3 ). Then, under mild sedation and local anesthesia, both the cleft on the lip was operated and the incisors were removed from the maxilla (figure 4). It was seen that the calf's non closing mouth due to incisive teeth in maxilla before the operation, return to normal and there was no function problem (figure 5).

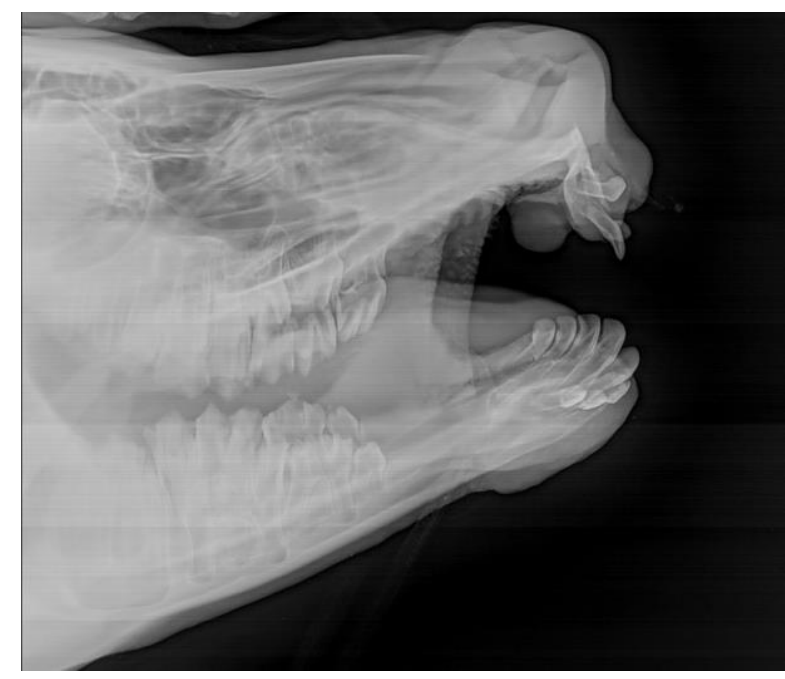

Figure 3. X-ray view of incisive teeth in Maxilla 


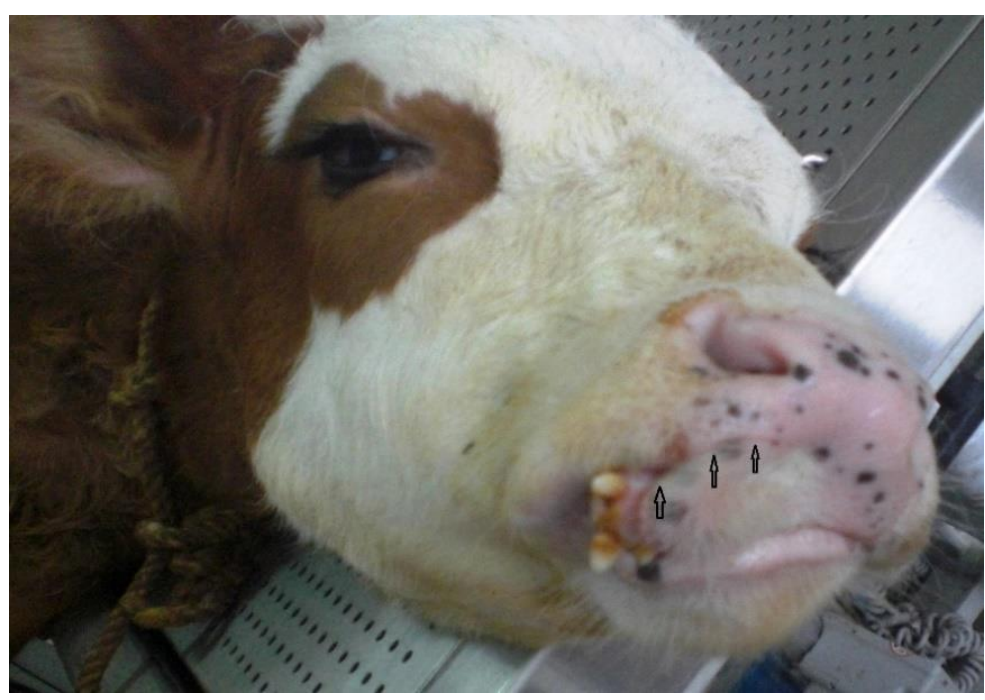

Figure 4. Congenital pathological slit on the upper lip (Black arrows)

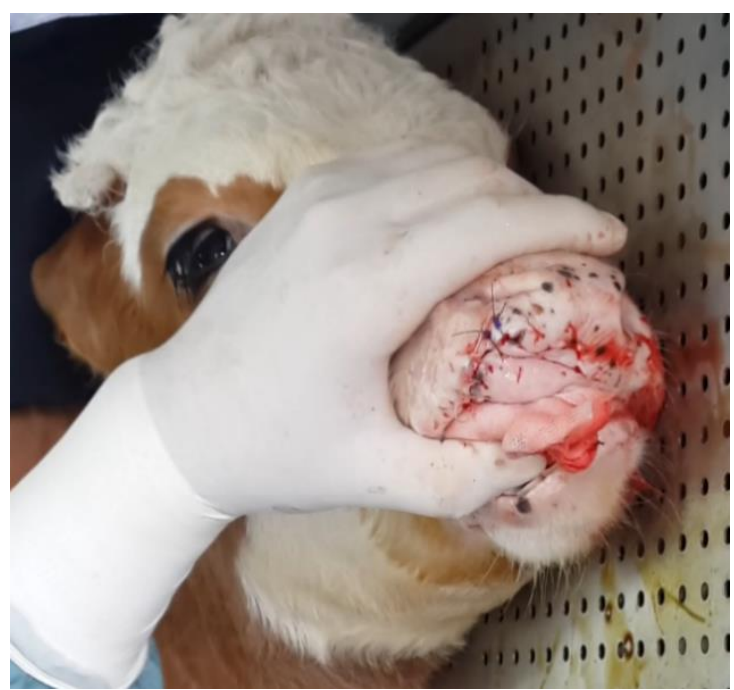

Figure 5. Post-operative view.

\section{DISCUSSION AND CONCLUSION}

A great number of congenital abnormalities and deformities of the skeleton structure $(13,14)$ and intestinal tract have been reported in domestic animals (15). Congenital abnormalities may be multiple $(13,14,16,17)$ or may affect single parts of organ systems (18).

However, as mentioned above, although congenital anomalies were encountered in many different organs during delivery in ruminants, no information about maxillary incisive tooth formation was found in the literature search. On the other hand, in a calf with multiple organ anomalies it was reported that there was only one molar tooth in the mandible without incisive tooth formation (19). They point out that the etiology of the large number of teeth in humans is still unclear. A number of theories have been postulated to try to explain their presence, including atavism (evolutionary throwback), tooth germ dichotomy, hyperactivity of the dental lamina, and genetic and environmental factors $(20,21)$.

The incidence of maxillary incisive teeth in ruminants and other domestic animals has not been observed so far, so there is no idea about the etiology. However, according to our anamnesis information, there was no similar anomaly in the mother of the calf in question and in the other calves in two previous births. Therefore, it is thought that a genetic phenomenon is a weak possibility (22). It is thought that the antiparasitic drug used at the beginning of pregnancy may be a possible etiological cause (23). According to the authors, in most cases, multiple supernumerary teeth are associated with other conditions or defects such as cleft palate and cleft lip, or with variable syndromes. In this case, the cleft and hairy events on the upper lip supports the literature findings (2).

According to the claim of Wang and Fan while most supernumerary teeth can be isolated cases, some may be genetic or even some may be syndrome-related events. What caused the formation of these teeth has not yet been determined. A number of theories have been put forward to explain their existence, including atavism (evolutionary decline), the tooth germ dilemma, hyperactivity of the dental lamina, and genetic and environmental factors in humans (7).

Wang and Fan stated that the reported prevalence of supernumerary teeth in human ranges from $0.2 \%$ to $0.8 \%$ in the deciduous dentition, and ranges from $0.5 \%$ to $5.3 \%$ in the permanent dentition with geographic variations. However, there is no scientific published case in domestic animals and therefore no idea about its prevalence (7).

In the literature search, in the extensive studies on congenital malformations, maxillary incisive tooth formation cases were not found in calves. In the light of the information we have obtained, it is thought that the first maxillary incisive tooth phenomenon seen in Southern Anatolian Red and Simental crossbred calves is considered to be important.

\section{REFERENCES}

1. Whitlock BK, Kaiser L, Maxwell HS. (2008). Heritable Bovine Fetal Abnormalities. Theriogenology. 70: 535-549.

2. Özcan K, Gürbulak K, Takçi I, Özen H, Kaçar C, Pancarci MŞ. (2006). Atypical Cyclopia in a Brown Swiss Cross Calf: A Case Report. Anat Histol Embryol. 35(3): 152-154.

3. Smolec O, Kos J, Vnuk D, Stejskal M, Brkljaca Bottegaro N, Zobel R. (2010). Multiple Congenital Malformation in a Simental Female Calf: A Case Report. Vet Med. 55(4): 194-198.

4. Noh DH, Jeong WI, Lee CS, et al. (2003). Multiple Congenital Malformations in a Holstein Calf. J Comp Pathol. 129(4): 313315.

5. Aydın M, Karan M, Yüksel M. (2006). Buzağılarda Rastlanılan Farklı Schistosoma Reflexum Olgularının Anatomik Olarak Karşılaştırılması. FÜ Sağ Bil Derg. 20(3): 249-252.

6. Belge A, Gönenci R, Biricik HS, Ormancı S. (2000). Buzağılarda Doğmasal Anomali Olguları. YYU Vet Fak Derg.11(2): 23-26.

7. Wang XP, Jiabing F. (2011). Molecular Genetics of Supernumerary Tooth Formation. Genesis. 49(4): 261-277.

8. Pace JE, Wakeman DL. (2003). Determining the Age of Cattle by Their Teeth. Access: https://ufdc.ufl.edu/IR00004537/00001. Date of Access: 04.10.2020. 
9. Hall JB, Silver S. (2009). Nutrition and Feeding of the Cow-Calf Herd: Digestive System of the Cow. Anim Feed Sci Technol. 400010.

10. Sinai NL, Dadaian RH, Kass PH, Verstraete FJM. (2014). Dental Pathology of the California Sea Lion (Zalophus californianus). J Comp Path. Vol.151: 113-121.

11. Drögemüller C, Kuıper H, Peters M, Guıonaud S, Dıstl O, Leeb L. (2002). Congenital Hypotrichosis with Anodontia in Cattle: A Genetic, Clinical and Histological Analysis. Vet Dermatol. 13: 307-313.

12. Pearson LK. Congenital and Inherited Anomalies of the Teeth. Access: http://www.merckvetmanual.com/digestive-system/congenital-and-inherited-anomalies-of-the-digestive-system/congenital-and-inherited-anomalies-of-the-teeth. Date of Access:05.07. 2016.

13. Agerholm SJ, Bendixen C, Andersen O, Arnbjerg J. (2001). Complex Vertebral Malformation in Holstein Calves. J Vet Diagn Invest. 13: 283-289

14. Duncan Jr RB, Carrig CB, Agerholm JS, Bendixen C. (2001). Complex

Vertebral Malformation in a Holstein Calf: Report of a Case in the

USA. J Vet Diagn Invest. 13:333-6.

15. Lapointe JM, Lachance S, Steffen DJ. (2000). Tibial Hemimelia, Meningocele, and Abdominal Hernia in Shorthorn Cattle. Vet Pathol. 37:508-11.

16. Camon, Sabate JD, Franch J, Lopez-Bejar MA, et al. (1990). Associated Multiple Congenital Malformations in Domestic Animals. Contribution of Four Cases. J Vet Med. 37: 659-668.
17. Newman SJ, Bailey TL, Jones JC, DiGrassie WA, Whittier WD. (1999). Multiple Congenital Anomalies in a Calf. J Vet Diagn Invest. 11: 368-371.

18. Doige CE, Townsend HG, Janzen ED, McGowan M. (1990). Congenital Spinal Stenosis in Beef Calves in Western Canada. Vet Pathol. 27(1):16-25.

19. Barlund CS, Edwar GC, Tosso L, Drögemüller C, Palmer CW. (2007). Congenital Hypotrichosis and Partial Anodontia in a Crossbred Beef Calf. Can Vet J. 48:612-614

20. Primosch RE. (1981). Anterior Supernumerary Teeth-Assessment and Surgical Intervention in Children. Pediatr Dent. 3:204-215

21. Saarenmaa L. (1951). The Origin of Supernumerary Teeth. Acta Odontol Scand. 9:293-303.

22. Belge A, Gönenci R, Selçukbiricik H, Ormanci S. (2000). Buzağılarda Doğmasal Anomali Olguları. YYU Vet Fak Derg. 11(2): 23 26.

23. Aksoy Ö. Kılıç E. Öztürk S. Özaydın I. Kurt B. Baran V. (2006) Buzağı, Kuzu ve Oğlaklarda Karşılaşılan Doğmasal Anomaliler: 1996-2005 (262 Olgu). Kafkas Üniv Vet Fak Derg. 12(2):147154.

Corresponding Author:

Elif EKINCI

Department of Wild Animals and Ecology, Faculty of Veterinary Medicine, Dicle University, Diyarbakir, TURKEY E-posta: vethekelf 21@hotmail.com 